University of Nebraska - Lincoln

DigitalCommons@University of Nebraska - Lincoln

$3-1-2000$

\title{
Characterization of North American Armillaria species by nuclear DNA content and RFLP analysis
}

\author{
Mee-Sook Kim \\ University of Nebraska-Lincoln \\ Ned Klopfenstein \\ University of Nebraska-Lincoln, nklopfenstein@fs.fed.us \\ Geral I. McDonald \\ USDA Forest Service, RMRS, Forestry Sciences Laboratory \\ Kathiravetpillai Arumuganathan \\ University of Nebraska-Lincoln \\ Anne K. Vidaver \\ University of Nebraska-Lincoln, avidaver1@unl.edu
}

Follow this and additional works at: https://digitalcommons.unl.edu/plantpathpapers

Part of the Plant Pathology Commons

Kim, Mee-Sook; Klopfenstein, Ned; McDonald, Geral I.; Arumuganathan, Kathiravetpillai; and Vidaver, Anne K., "Characterization of North American Armillaria species by nuclear DNA content and RFLP analysis" (2000). Papers in Plant Pathology. 75.

https://digitalcommons.unl.edu/plantpathpapers/75

This Article is brought to you for free and open access by the Plant Pathology Department at DigitalCommons@University of Nebraska - Lincoln. It has been accepted for inclusion in Papers in Plant Pathology by an authorized administrator of DigitalCommons@University of Nebraska - Lincoln. 


\section{Characterization of North American Armillaria species by nuclear DNA content and RFLP analysis ${ }^{1}$}

\author{
Mee-Sook Kim ${ }^{2}$ \\ Department of Plant Pathology, University of \\ Nebraska, Lincoln, Nebraska 68583-0722 \\ Ned B. Klopfenstein \\ Geral I. McDonald \\ USDA Forest Service, RMRS, Forestry Sciences \\ Laboratory, 1221 S. Main, Moscow, Idaho 83843- \\ 4298
}

Kathiravetpillai Arumuganathan

Center for Biotechnology, University of Nebraska, Lincoln, Nebraska 68588-0665

Anne K. Vidaver

Department of Plant Pathology, University of Nebraska, Lincoln, Nebraska 68583-0722

\begin{abstract}
Twenty-six isolates representing nine North American Armillaria species were investigated with flow cytometry and RFLP (restriction fragment length polymorphism) analyses to determine their nuclear DNA content and RFLP profile. Three putatively diploid isolates of A. ostoyae, A. gemina, A. calvescens, A. sinapina, A. mellea, A. gallica, A. nabsnona, and North American Biological Species (NABS) X were analyzed, and two putatively diploid isolates of NABS XI also were analyzed. Nuclear DNA contents of Armillaria species were 0.11-0.17 pg per nucleus $\left(55-84 \times 10^{6} \mathrm{bp} / \mathrm{C}\right)$, depending on species. Among the nine North American Armillaria species tested, A. ostoyae, A. gemina, and A. mellea possessed relatively small nuclear DNA contents $(0.11-0.12 \mathrm{pg}$ per nucleus), whereas $A$. gallica possessed a relatively large nuclear DNA content $(0.17$ pg per nucleus). $A$. nabsnona has a slightly larger nuclear DNA content (0.13 pg per nucleus) than $A$. ostoyae, A. gemina, and A. mellea. Other species (A. calvescens, A. sinapina, NABS X, and NABS XI) possessed moderate nuclear DNA contents (ca 0.15 pg per nucleus). Polymerase chain reaction (PCR) and RFLP of the intergenic spacer region-1 (IGS-1) generated banding patterns for nine Armillaria species. In addition to previously reported banding patterns, new banding patterns are

Accepted for publication March 24, 2000.

${ }^{1}$ This manuscript has been assigned Journal Series No. 12652, Agricultural Research Division, University of Nebraska.

${ }^{2}$ Current address: Department of Forest Resources, University of Idaho, Moscow, ID 83844 USA; email: meeskim@uidaho.edu
\end{abstract}

presented for A. gemina, A. calvescens, A. mellea, and A. gallica.

Key Words: flow cytometry, genome size, intergenic spacer, North American Biological Species

\section{INTRODUCTION}

The genus Armillaria consists of about nine species in North America. Species were originally defined using biological and morphological characteristics (Anderson and Ullrich 1979, Korhonen 1978); however, molecular genetic studies of these species allow new evaluations of taxonomic relationships. Information on genome size and DNA sequence data for Armillaria species will facilitate investigations of their phylogenetic relationships, ecological roles in forest ecosystems, and gene flow within and among different species. Since 1985, several studies report qualitative comparisons of DNA content in nuclei of Armillaria species; however, this study represents the first quantitative determinations of nuclear DNA contents in Armillaria species.

In previous studies, microspectrophotometric techniques were used to detect differences in nuclear DNA content between two geographically distinct isolates of Armillaria species (Motta 1985). Microspectrophotometric analysis also revealed relative differences in nuclear DNA content in basidioma tissue of A. mellea s. s. and A. bulbosa (= A. gallica) (Motta et al 1986). Similar techniques were used to determine that monokaryotic cells of mature A. bulbosa basidiocarps contained haploid nuclei (Peabody and Peabody 1985). Subsequently, nuclear volume and DNA content were estimated for three life-cycle stages of A. bulbosa (Peabody and Peabody 1986). Fluorescence microscopy also allowed relative comparisons of nuclear DNA content at various developmental stages of Japanese A. mellea s. s. (Ota et al 1998). Although results from microspectrophotometry methods can be informative, the methods are slow, difficult to use, and measurement is practically limited to about 100 nuclei per fungal sample (Eilam et al 1994).

Laser flow cytometry is a relatively new technique that allows quantitative measurement of DNA content. The laser flow cytometer measures the fluorescence intensity of a DNA-binding stain such as pro- 
pidium iodide to determine DNA content of cell nuclei (Arumuganathan and Earle 1991, Hultquist et al 1996). Thousands of propidium iodide-stained nuclei can be measured in a few seconds, and data can be automatically analyzed using software that determines the mean position of nuclear peaks from the sample. Although the availability of laser flow cytometry has led to its widespread use in basic biology and medicine, relatively few reports utilizing flow cytometry in mycological studies have been published (Allman 1992, Bianciotto and Bonfante 1992, Bianciotto et al 1995, Eilam et al 1994). Laser flow cytometry was conducted in conjunction with protoplast isolation to demonstrate comparatively a haploid nuclear condition in secondary mycelium of A. mellea s. s. (Darmono and Burdsall 1993). However, quantification of DNA content in Armillaria species has not been reported previously. Previous difficulties in DNA quantification were associated with deficiencies in methodologies including measuring equipment and general techniques to separate and uniformly stain mycelial nuclei for precise quantitative analysis.

Recently, molecular genetic methods were developed to augment identification of Armillaria species (Anderson and Stasovski 1992, Anderson et al 1987, 1989, Harrington and Wingfield 1995, Jahnke et al 1987, Miller et al 1994, Smith and Anderson 1989, Smith et al 1990, Schulze et al 1995, 1997). Anderson and Stasovski (1992) used polymerase chain reaction (PCR) to amplify the Intergenic Spacer (IGS) of the ribosomal RNA operon, and sequenced this region for several Armillaria species to determine phylogenetic relationships. Based on the IGS-1 sequences, Harrington and Wingfield (1995) developed a simplified PCR-based method in which the IGS-1 region is amplified, then cut with restriction endonucleases to produce RFLPs that are species specific. Their PCR-based method is especially practical because mycelial scrapings frequently provide sufficient template DNA for species identification. Subsequently, this method has been widely applied to augment identification of Armillaria species (Banik and Burdsall 1998, Banik et al 1996, Baumgartner et al 1997, Frontz et al 1998, Sung et al 1997, Volk et al 1996, White et al 1998).

The objectives of this study were: (i) to quantify nuclear DNA content of nine North American $A r$ millaria species, (ii) to verify whether differences exist in the genome sizes among nine Armillaria species investigated, and (iii) to determine the IGS-1 diagnostic banding patterns using the PCR-RFLP method for species identification of nine Armillaria species. These objectives provide a characterized set of diploid tester strains for use in biological and taxonomic studies of Armillaria species.

\section{MATERIALS AND METHODS}

Tested species included A. ostoyae (Romagn.) Henr., A. gemina Bérubé \& Dessureault, A. calvescens Bérubé \& Dessureault, $A$. sinapina Bérubé \& Dessureault, $A$. mellea (Vahl: Fr.) Kummer, A. gallica Marxmüller \& Romagnesi, A. nabsnona Volk \& Burdsall, NABS X, and NABS XI. Three isolates of each of the nine described species of Armillaria in North America were included in the study, with the exception of NABS XI for which only two isolates were included (TABLE I). Isolates originated from basidioma (stipe or context) tissue or mass-spore cultures, and were previously identified by various investigators using haploid $\times$ haploid mating or haploid $\times$ diploid pairing tests (TABLE I). To ensure that each isolate represented a distinct genet (vegetative clone), isolates were selected from different geographic regions or were tested by somatic pairing (Anderson and Kohn 1995) (TABLE I). For use in flow cytometry and RFLP analyses, isolates were maintained in Petri dishes on $3 \%$ malt agar medium (3\% malt extract, $1 \%$ peptone, $3 \%$ glucose, $1.5 \%$ agar) and incubated at $22 \mathrm{C}$ in the dark.

Armillaria isolates were grown for $6 \mathrm{wk}$ on $3 \%$ malt agar medium. Mycelia (ca $30 \mathrm{mg}$ ) of each isolate were dissected away from the medium, fixed in $4 \%(\mathrm{w} / \mathrm{v})$ formaldehyde in Tris buffer (10 mM Tris, $10 \mathrm{mM} \mathrm{Na-EDTA,} 100 \mathrm{mM} \mathrm{NaCl}$, $0.1 \%$ Triton-100, $\mathrm{pH} 7.4$ ) (Bianciotto et al 1995) for $15 \mathrm{~min}$, and then washed twice in Tris buffer. Intact nuclei were isolated in Tris buffer by repeatedly chopping the mycelia with a sharp scalpel blade. Suspended nuclei were filtered through nylon filters with a $30-\mu \mathrm{m}$-pore diam. To a $0.7-\mathrm{mL}$ suspension of nuclei, $2.5 \mu \mathrm{L}$ RNAse $(500 \mu \mathrm{g} / \mathrm{mL})$ was added, followed by gentle mixing with $20 \mu \mathrm{L}$ propidium iodide solution $(5 \mathrm{mg} / \mathrm{mL})$. All nuclear isolation procedures were conducted on ice. Nuclear suspensions were incubated in the dark for $20 \mathrm{~min}$ at room temperature. Fluorescence of the nuclear stain propidium iodide was measured at the University of Nebraska-Center for Biotechnology Flow Cytometry Core Research Facilities using a FACScan Flow Cytometer (Becton Dickinson, San Jose, California). Debris was excluded from the analyses by raising the FL3 threshold, and the appropriate threshold value was determined experimentally. Each measurement of fungal DNA content was based on 10000 scanned nuclei. The internal standard used for comparison was chicken red blood cells (CRBC), for which the DNA content is known $(2.33 \mathrm{pg} / 2 \mathrm{C})$ (Galbraith et al 1983). All flow cytometry data were evaluated using linear and logarithmic scales to assure normal distribution. For each sample and the internal standard, the mean positions of nuclear peaks were determined by analysis using CellQuest software (Becton Dickinson, San Jose, California). The formula used for converting fluorescence intensity values to DNA content was: nuclear DNA content $=$ (mean fluorescence intensity of sample peak) $/($ mean fluorescence intensity of the standard peak) $\times$ DNA content of the standard $(2.33 \mathrm{pg})$. All flow cytometry analyses were conducted four times per isolate. The analysis of variance (ANOVA) for species means was performed using the General Linear Model (GLM) procedure (SAS 1996). A Tukey's Honestly Significant Differences test $(\alpha=0.05)$ was used to determine differences among Armillaria species. 
TABLE I. Species of Armillaria, geographic origin, and collections used as sources for flow cytometry of nuclear DNA and RFLP analyses

\begin{tabular}{|c|c|c|c|c|}
\hline Species & Collection & Isolate $^{\mathrm{a}}$ & Origin & Source tissue \\
\hline \multirow[t]{3}{*}{ A. ostoyae } & DMR20 & ST1 & New Hampshire, USA & multisporous \\
\hline & AMM9067c & ST2 & Washington, USA & basidioma \\
\hline & $\mathrm{P} 1404^{\mathrm{d}}$ & P1404 & Idaho, USA & basidioma \\
\hline \multirow[t]{3}{*}{ A. gemina } & JJW153e & ST8 & New York, USA & basidioma \\
\hline & JJW64" & ST9 & New York, USA & basidioma \\
\hline & MIELKE & ST11 & West Virginia, USA & unknown \\
\hline \multirow[t]{3}{*}{ A. calvescens } & $J B 56 A^{f}$ & ST3 & Quebec, Can & basidioma \\
\hline & PR-3c & ST17 & Michigan, USA & basidioma \\
\hline & FFC- $7 \mathrm{c}$ & ST18 & Michigan, USA & basidioma \\
\hline \multirow[t]{3}{*}{ A. sinapina } & SP81-1g & M50 & British Columbia, Can & basidioma \\
\hline & AMM9065 & ST12 & Washington, USA & basidioma \\
\hline & $\mathrm{CF}-2^{\mathrm{c}}$ & ST13 & Michigan, USA & multisporous \\
\hline \multirow[t]{3}{*}{ A. mellea } & GB934 ${ }^{c}$ & ST5 & Virginia, USA & multisporous \\
\hline & $\mathrm{A} 3^{\mathrm{c}}$ & ST20 & Wisconsin, USA & basidioma \\
\hline & TCH-2c & ST21 & New Hampshire, USA & multisporous \\
\hline \multirow[t]{3}{*}{ A. gallica } & SP81-29g & M70 & British Columbia, Can & basidioma \\
\hline & EL-1c & ST22 & Michigan, USA & basidioma \\
\hline & MA-1 ${ }^{\mathrm{c}}$ & ST23 & Wisconsin, USA & basidioma \\
\hline \multirow[t]{3}{*}{ A. nabsnona } & $\mathrm{C} 21^{\mathrm{d}}$ & $\mathrm{C} 21$ & Idaho, USA & basidioma \\
\hline & M90s & M90 & British Columbia, Can & basidioma \\
\hline & SHAW, $\mathrm{C}^{\mathrm{c}}$ & ST16 & Alaska, USA & multisporous \\
\hline \multirow[t]{3}{*}{ NABS $X^{b}$} & $837^{\mathrm{d}}$ & 837 & Idaho, USA & basidioma \\
\hline & D82 ${ }^{\mathrm{d}}$ & D82 & Idaho, USA & basidioma \\
\hline & POR $100^{d}$ & POR100 & Idaho, USA & basidioma \\
\hline \multirow{2}{*}{ NABS XI } & SP82-14g & M110 & British Columbia, Can & basidioma \\
\hline & SP83-07g & $\mathrm{S} 20$ & British Columbia, Can & basidioma \\
\hline
\end{tabular}

a Identification code in this paper.

${ }^{\mathrm{b}} \mathrm{NABS}=$ North American Biological Species.

${ }^{\mathrm{C}}$ Identified by USDA Forest Service Center for Forest Mycology Research, Madison, Wisconsin.

${ }^{\mathrm{d}}$ Identified by G. McDonald.

e Identified by J. Worrall.

${ }^{\mathrm{f}}$ Identified by J. Bérubé.

$\mathrm{g}$ Identified by $\mathrm{D}$. Morrison.

Fluorescent stained nuclei were observed with fluorescence microscopy to determine the number of nuclei per cell. Actively growing mycelia were dissected away from the $3 \%$ malt agar medium with a scalpel, then fixed in FAA ( $4 \%$ formaldehyde, $2.5 \%$ acetic acid, and $47.5 \%$ ethanol in 0.1 $\mathrm{M}$ phosphate buffer, $\mathrm{pH}$ 7.0) for $6 \mathrm{~h}$ at $4 \mathrm{C}$, then rinsed four times in $0.1 \mathrm{M}$ phosphate buffer. Fixed nuclei were stained and mounted in Vectashield ${ }^{\circledR}$ mounting medium with $1.5 \mu \mathrm{g} / \mathrm{mL} 4^{\prime}$,6-diamidino-2-phenylindole (DAPI) (Vector Laboratories, Inc., Burlingame, California). Specimens were observed using an oil immersion lens and UV excitation light on a fluorescence microscope (Olympus BX60).

The IGS-1 region between the 3 ' end of the 25S (large subunit) ribosomal RNA (rRNA) gene and the $5^{\prime}$ end of the 5S rRNA gene was amplified using PCR. Template DNA was derived from scrapings of actively growing mycelial cultures (3-4 wk old). Primers LR12R (Veldman et al 1981) and O-1 (Duchesne and Anderson 1990) were used to amplify the IGS-1 region. Each $100-\mu \mathrm{L}$ reaction mixture con- tained template DNA from a mycelial scraping (or no DNA template for negative control), 2.5 units Taq polymerase (Perkin-Elmer, Branchberg, New Jersey), PCR reaction buffer (supplied with Taq enzyme), $4 \mathrm{mM} \mathrm{MgCl}_{2}, 200 \mu \mathrm{M} \mathrm{d}$ NTPs, and $0.5 \mu \mathrm{M}$ of each primer (LR12R and O-1). After an initial denaturation step at $95 \mathrm{C}$ for $90 \mathrm{~s}$, PCR was conducted using 35 cycles of $60 \mathrm{C}$ for $40 \mathrm{~s}$ (annealing), $72 \mathrm{C}$ for $2 \mathrm{~min}$ (extension), and $90 \mathrm{C}$ for $30 \mathrm{~s}$ (denaturation) using a Perkin-Elmer (480) thermocycler (Harrington and Wingfield 1995). A final extension step at $72 \mathrm{C}$ for $10 \mathrm{~min}$ was conducted to ensure complete amplification into a double-stranded product.

Restriction digestions were conducted with aliquots (e.g., 10-15 $\mu \mathrm{L}$ ) from PCR amplification mixtures. Because the enzyme Alu I typically produces the most polymorphisms useful for species identification, it was the primary restriction endonuclease used on all PCR products (Harrington and Wingfield 1995). When Alu I (New England BioLabs, Inc., Beverly, Massachusetts) restriction cuts were insufficient to distinguish species, other restriction endonucleases 
TABLE II. Alu I restriction fragment sizes of intergenic spacer (IGS-1) regions and nuclear DNA content of nine Armillaria species

\begin{tabular}{|c|c|c|c|}
\hline Species & Isolate & Restriction fragments $(\mathrm{bp})^{\mathrm{a}}$ & $\begin{array}{l}\text { DNA content }{ }^{\mathrm{b}} \\
\text { (pg/nucleus) }\end{array}$ \\
\hline \multirow[t]{3}{*}{ A. ostoyae } & ST1 & $308( \pm 3), 196( \pm 2), 138( \pm 1)$ & $0.117 \pm 0.002$ \\
\hline & ST2 & $308( \pm 3), 196( \pm 2), 138( \pm 1), 93( \pm 3)$ & $0.109 \pm 0.002$ \\
\hline & P1404 & $308( \pm 3), 196( \pm 2), 138( \pm 1), 93( \pm 3)$ & $0114 \pm 0.001$ \\
\hline \multirow[t]{3}{*}{ A. gemina } & ST8 & $308( \pm 3), 196( \pm 2), 168( \pm 2), 138( \pm 1), 93( \pm 3)$ & $0.121 \pm 0.003$ \\
\hline & ST9 & $308( \pm 3), 196( \pm 2), 138( \pm 1), 93( \pm 3)$ & $0.120 \pm 0.003$ \\
\hline & ST11 & $308( \pm 3), 196( \pm 2), 138( \pm 1), 93( \pm 3)$ & $0.118 \pm 0.002$ \\
\hline \multirow[t]{3}{*}{ A. calvescens } & ST3 & $401( \pm 6), 239( \pm 4), 184( \pm 2)$ & $0.152 \pm 0.003$ \\
\hline & ST17 & $401( \pm 6), 239( \pm 4), 184( \pm 2)$ & $0.159 \pm 0.001$ \\
\hline & ST18 & $401( \pm 6), 239( \pm 4), 184( \pm 2)$ & $0.150 \pm 0.002$ \\
\hline \multirow[t]{3}{*}{ A. sinapina } & M50 & $402( \pm 7), 196( \pm 2), 184( \pm 2), 139( \pm 1)$ & $0.151 \pm 0.002$ \\
\hline & ST12 & $401( \pm 6), 239( \pm 4), 184( \pm 2)$ & $0.149 \pm 0.002$ \\
\hline & ST13 & $401( \pm 6), 239( \pm 4), 196( \pm 2), 184( \pm 2), 139( \pm 1)$ & $0.237 \pm 0.003$ \\
\hline \multirow[t]{3}{*}{ A. mellea } & ST5 & $472( \pm 6), 186( \pm 2), 175( \pm 1), 153( \pm 1)$ & $0.120 \pm 0.002$ \\
\hline & ST20 & $473( \pm 7), 175( \pm 2)$ & $0.122 \pm 0.003$ \\
\hline & ST21 & $473( \pm 7), 175( \pm 2)$ & $0.125 \pm 0.002$ \\
\hline \multirow[t]{3}{*}{ A. gallica } & M70 & $398( \pm 2), 249( \pm 5), 236( \pm 2), 180( \pm 3)$ & $0.165 \pm 0.003$ \\
\hline & ST22 & $584( \pm 8), 398( \pm 2), 235( \pm 3), 180( \pm 2)$ & $0.169 \pm 0.002$ \\
\hline & ST23 & $585( \pm 8), 234( \pm 4)$ & $0.169 \pm 0.003$ \\
\hline \multirow[t]{3}{*}{ A. nabsnona } & C21 & $308( \pm 4), 229( \pm 3), 196( \pm 2)$ & $0.133 \pm 0.001$ \\
\hline & M90 & $541( \pm 7), 308( \pm 4), 229( \pm 3), 196( \pm 2)$ & $0.131 \pm 0.004$ \\
\hline & ST16 & $541( \pm 7), 197( \pm 1)$ & $0.134 \pm 0.001$ \\
\hline \multirow[t]{3}{*}{ NABS $\mathrm{X}$} & 837 & $401( \pm 3), 184( \pm 1), 145( \pm 1)$ & $0.150 \pm 0.001$ \\
\hline & D82 & $401( \pm 3), 184( \pm 1), 145( \pm 1)$ & $0.153 \pm 0.002$ \\
\hline & POR100 & $401( \pm 3), 184( \pm 1), 145( \pm 1)$ & $0.153 \pm 0.003$ \\
\hline \multirow{2}{*}{ NABS XI } & M110 & $401( \pm 3), 197( \pm 1), 184( \pm 1)$ & $0.148 \pm 0.002$ \\
\hline & S20 & $401( \pm 3), 197( \pm 1), 184( \pm 1)$ & $0.156 \pm 0.004$ \\
\hline
\end{tabular}

${ }^{a}$ Fragment sizes were determined from DNA size standards (20 bp or $50 \mathrm{bp}$ ) using SigmaGel gel analysis software. Values represent the mean $( \pm \mathrm{SD})$ of three replications from three different gels.

b The standard used for comparison was chicken red blood cells, for which the DNA content $(2.33 \mathrm{pg} / 2 \mathrm{C})$ is known.

c Each number represents the mean \pm standard error of the mean of four replications. Each replication of Armillaria isolate DNA content was based on 10000 scanned nuclei.

(e.g., Bsm I, Dde I, EcoR I, Hae III, Hinc II, Nde I) (New England BioLabs, Inc., Beverly, Massachusetts) were used. Digestions were conducted using 5-10 units of restriction endonucleases for 8-12 h at $37 \mathrm{C}$.

Intact and restriction-digested PCR products were electrophoresed in 2.5\% MetaPhor ${ }^{\circledR}$ agarose (FMC BioProducts, Rockland, Maine) gels using 0.5X TBE $(89 \mathrm{mM}$ Tris, $89 \mathrm{mM}$ boric acid, and $2 \mathrm{mM}$ EDTA) buffer. Electrophoresis was conducted at a constant $100 \mathrm{~V}$ for $4 \mathrm{~h}$. Gels were stained with ethidium bromide $(0.5 \mu \mathrm{g} / \mathrm{mL})$ and bands were visualized using UV light. Gel images were analyzed with SigmaGel ${ }^{\text {TWW }}$ gel analysis software (SPSS Science, Chicago, Illinois).

\section{RESULTS}

Nuclear DNA contents of nine Armillaria species as determined by laser flow cytometry are presented in TABLE II. Nuclear DNA contents varied 0.109-0.237 pg per nucleus and showed small variances with a CV (coefficient of variation) ranging $6.4-10.8 \%(8.5 \%$ of mean CV) (Table II, Fig. 1). Armillaria ostoyae, $A$. gemina, and $A$. mellea have comparatively small nuclear DNA contents (0.109-0.125 pg per nucleus) (TABLE II); however, a significant difference was noted between $A$. ostoyae and $A$. mellea (TABLE III). No significant differences in nuclear DNA contents were observed among $A$. calvescens, A. sinapina (except isolate ST13), NABS X, and NABS XI (0.148-0.159 pg per nucleus) (TABles II, III). Compared to the other species, A. gallica shows a relatively large nuclear DNA content (0.165-0.169 pg per nucleus) (TABLE II). Armillaria nabsnona has a slightly larger nuclear DNA content (0.131-0.134 pg per nucleus) than A. ostoyae, A. gemina, and A. mellea (TABLE II), and a significant difference was noted between $A$. nabsnona and A. ostoyae, A. gemina, or A. mellea (TABLE III). Among 26 isolates, A. sinapina isolate ST13 showed the largest nuclear DNA content $(0.237 \mathrm{pg}$ per nucleus), a size indicative of a triploid nuclear condition (TABLE II, FIG. 1E). A histogram of fluo- 

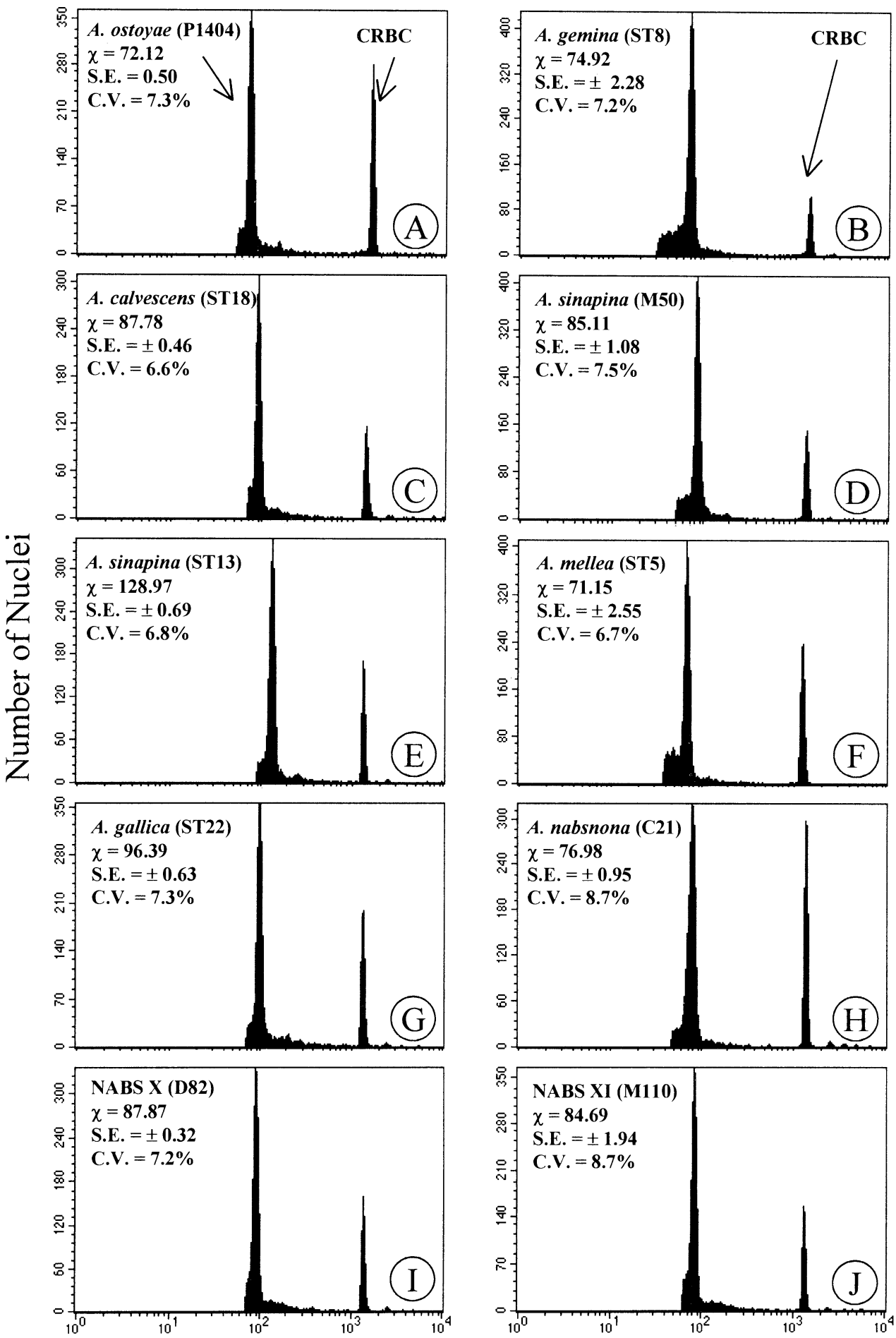

\section{Log PI Fluorescence Intensity (arbitrary units)}

FIG. 1. Representative histograms showing numbers of given fluorescence intensities obtained by flow cytometry for propidium iodide-stained nuclei from nine Armillaria species and chicken red blood cells (CRBC; 2.33 pg/nucleus). Isolates of Armillaria are described in TABLE I. The mean of $\log$ fluorescence intensities $(\chi)$, standard error (SE), and coefficient of variation $(\mathrm{CV})$ are listed for the peak from each isolate. 
TABLE III. Overall means and multiple mean comparisons of nuclear DNA contents of nine Armillaria species

\begin{tabular}{lcc}
\hline \multicolumn{1}{c}{ Species } & Samples $^{\mathrm{a}}$ & $\begin{array}{c}\text { DNA content } \mathrm{t}^{\mathrm{b}} \\
(\mathrm{pg} / \text { nucleus })\end{array}$ \\
\hline A. gallica & 12 & $0.168 \pm 0.001 \mathrm{~A}$ \\
A. calvescens & 12 & $0.153 \pm 0.001 \mathrm{~B}$ \\
NABS XI & 8 & $0.152 \pm 0.002 \mathrm{~B}$ \\
NABS X & 12 & $0.152 \pm 0.001 \mathrm{~B}$ \\
A. sinapina & 8 & $0.150 \pm 0.002 \mathrm{~B}$ \\
A. nabsnona & 12 & $0.133 \pm 0.002 \mathrm{C}$ \\
A. mellea & 12 & $0.122 \pm 0.001 \mathrm{D}$ \\
A. gemina & 12 & $0.120 \pm 0.002 \mathrm{DE}$ \\
A. ostoyae & 12 & $0.113 \pm 0.001 \mathrm{E}$ \\
\hline
\end{tabular}

a Three isolates of the nine described species of Armillaria species ( $A$. sinapina isolate ST13 was not included in this multiple mean comparisons test because it showed a triploid nuclear DNA content) were included in the study, with exception of NABS XI for which only two isolates were included. All flow cytometry analyses were conducted four times per isolate. Each replication of Armillaria isolate DNA content was based on 10000 scanned nuclei.

${ }^{\mathrm{b}}$ Mean nuclear DNA content $\pm \mathrm{SE}$ of the mean of each Armillaria species according to TABLE II. The same letters are not significantly different according to Tukey's Honestly Significant Difference test $(\alpha=0.05)$.

rescent events versus amount of fluorescence intensity revealed well-defined peaks with a normal distribution for all nine Armillaria species (FIG. 1). Fluorescence microscopic observations revealed a monokaryotic condition in all investigated isolates of Armillaria species.

Amplified DNA products corresponding to the intergenic spacer (IGS-1) region were ca 875 bp for $A$. mellea, and ca $920 \mathrm{bp}$ for A. ostoyae, A. gemina, A. calvescens, A. sinapina, A. gallica, A. nabsnona, NABS $\mathrm{X}$, and NABS XI. The restriction enzymes $A l u \mathrm{I}, B s m$ I, Dde I, EcoR I, Hae III, Hinc II, and Nde I were used to examine restriction sites within the amplified IGS1. One to three Alu I digestion patterns were found in each of the 9 taxa tested (TABLE II, FIG. 2). Sizes of Alu I digestion fragments for the nine Armillaria species are given in TABLE II, and fragment patterns of Alu I digestion are illustrated in Fig. 2. Some isolates (e.g., A. sinapina ST13) displayed additional bands with a pattern that represented composites of other isolates of the same species (FIG. 2). In these isolates, the total size of the fragments was greater than the size of the uncut IGS-1 region. Digestion with $A l u$ I produced characteristic diagnostic banding patterns for A. ostoyae (ST1, ST2, P1404) (FIG. 2 lanes 1-3), A. gemina (ST9, ST11) (FIG. 2 lanes 5, 6), A. sinapina (ST12, ST13, M50) (FIG. 2 lanes 10-12), A. mellea (ST20, ST21) (FIG. 2 lanes 14, 15), A. gallica (ST23) (FIG. 2 lane 18), A. nabsnona (C21, M90,
ST16) (FIG. 2 lanes 19-21), NABS X (837, D82, POR100) (FIG. 2 lanes 22-24), and NABS XI (M110, S20) (FIG. 2 lanes 25, 26) (TABLE II) (Banik et al 1996, Banik and Burdsall 1998, Harrington and Wingfield 1995, Volk et al 1996, White et al 1998). Restriction digestions with $A l u$ I could not differentiate between isolates of $A$. ostoyae (ST1, ST2, P1404) (FIG. 2 lanes 1-3) and A. gemina (ST9, ST11) (FIG. 2 lanes 5, 6) (TABLE II). However, restriction digestion with $N d e$ I produced a unique banding pattern for A. ostoyae. Amplified products of all A. ostoyae isolates were digested with $N d e$ I $(552,372 \mathrm{bp})$; however, the product of only one $A$. gemina isolate (ST9) was digested with $N d e$ I $(913,552,461,372$ bp). Using Alu I, Bsm I, Dde I, Hae III, Hinc II, and Nde I, isolates of A. calvescens (ST3, ST17, ST18) (FIG. 2 lanes 7-9) and A. sinapina (ST12) (FIG. 2 lane 10) showed the same RFLP banding pattern (TABLE II), and were indistinguishable. Compared to earlier studies (Banik and Burdsall 1998, Banik et al 1996, Harrington and Wingfield 1995, Volk et al 1996, White et al 1998), previously unreported RFLP patterns of A. gemina (ST8, FIG. 2 lane 4), A. calvescens (ST3, ST17, ST18, FIG. 2 lanes 7-9), A. mellea (ST5, FIG. 2 lane 13), and A. gallica (M70, ST22, FIG. 2 lanes 16,17$)$ were also observed.

\section{DISCUSSION}

This study provides genome size and IGS-1 RFLP data that further characterize a set of tester strains for use in biological and taxonomic studies of Armillaria species. Flow cytometry provided an effective means to measure genome sizes of Amillaria spp. The IGS-1 RFLP data is essential preliminary information for species identification and provides a basis for future molecular genetic studies.

Following their quantification of nuclear DNA in fungi, Duran and Gray (1989) suggested that genome size could assist their taxonomic classification of 70 smut fungi and two Neurospora species. Studying arbuscular mycorrhizal fungi, Bianciotto and Bonfante (1992) showed a $65 \%$ difference between nuclear DNA content of Gigaspora margarita Becker \& Hall (0.74-0.77 pg per nucleus) and Glomus versiforme (Karsten) Berch (0.25-0.27 pg per nucleus). Although more studies are needed to determine genome sizes of fungal taxa, available data suggest that genome size is useful for assessing taxonomic relationships.

The DNA-propidium iodide fluorescence measurements revealed marked differences among the nuclear DNA contents of nine Armillaria species (FIG. 1). Because this is the first report of quantitative measurements of nuclear DNA content in Armillaria spe- 

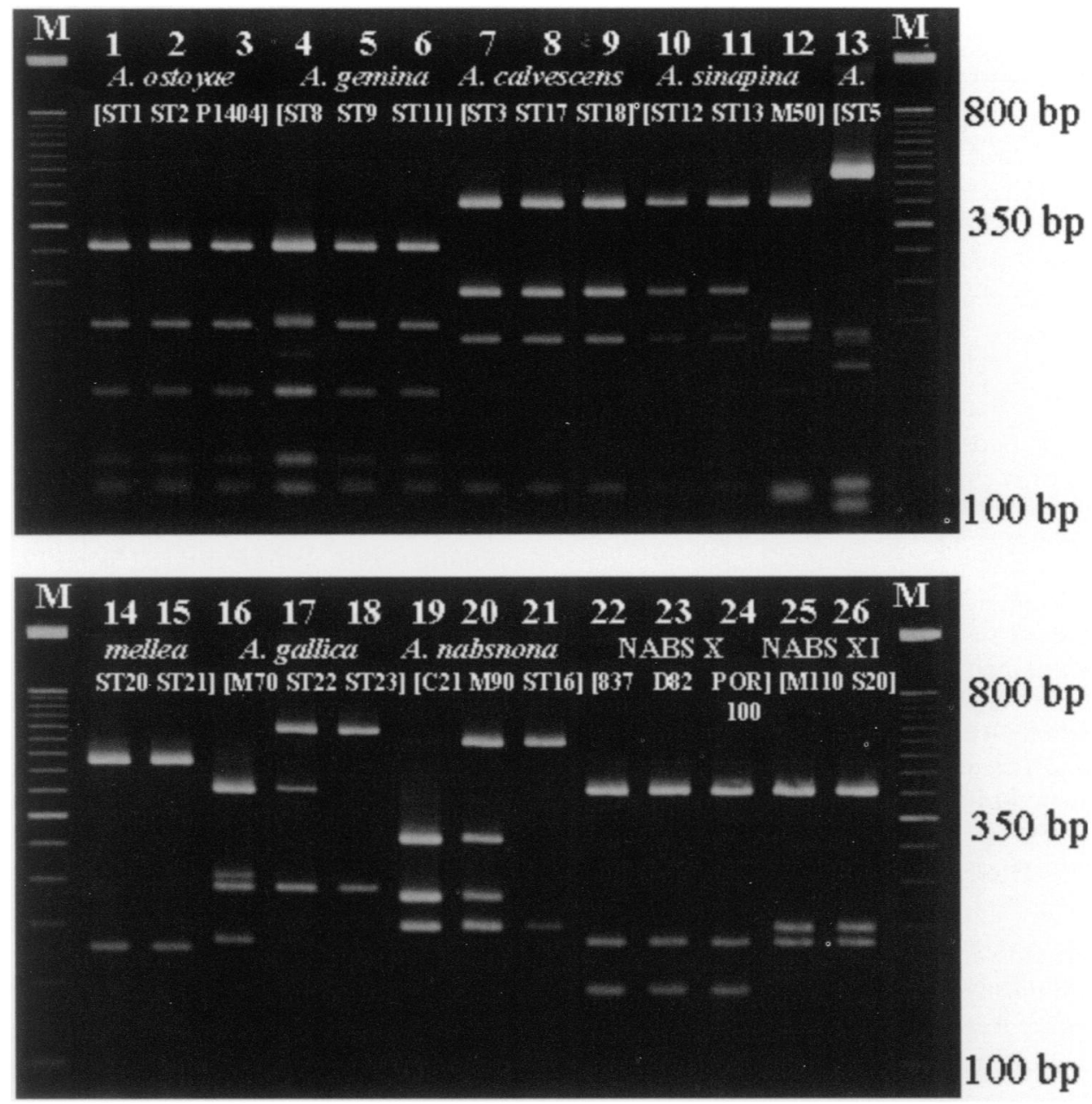

FIG. 2. PCR-RFLP band patterns of Armillaria species intergenic spacer (IGS-1) region digested with Alu I. Lanes: 1 (ST1), 2 (ST2), and 3 (P1404) = A. ostoyae, 4 (ST8), 5 (ST9), and 6 (ST11) = A. gemina; 7 (ST3), 8 (ST17), and 9 (ST18) $=A$. calvescens; 10 (ST12), 11 (ST13), and $12(\mathrm{M} 50)=A$. sinapina; 13 (ST5), 14 (ST20), and 15 (ST21) = A. mellea; 16 (M70), 17 (ST22), and 18 (ST23) = A. gallica; 19 (C21), 20 (M90), and 21 (ST16) = A. nabsnona; 22 (837), 23 (D82), and $24($ POR100) $=$ North American Biological Species (NABS) X; 25 (M110) and 26 (S20) = NABS XI. Size markers (50 bp) in base pairs are shown on far left and far right.

cies, other independent measurements are needed for comparison. In our preliminary studies, flow cytometry was used on basidiospore derived cultures to determine haploid genome sizes of A. sinapina (ca $0.08 \mathrm{pg}$ per nucleus), NABS X (ca $0.08 \mathrm{pg}$ per nucleus), and NABS XI (ca 0.08 pg per nucleus). Matings of basidiospore-derived cultures of NABS X isolates produced diploid mycelia with DNA contents of ca 0.15-0.16 pg per nucleus which corresponded to the nuclear DNA content of cultures derived from the parental basidiomata (Kim et al unpubl).

Nuclear DNA contents of $A$. ostoyae, A. gemina, $A$. calvescens, $A$. sinapina, A. mellea, A. nabsnona, NABS $\mathrm{X}$, and NABS XI were significantly different from $A$. gallica (TABLE III). Armillaria gallica had a nuclear DNA content approximately $40 \%$ larger than $A$. ostoyae, A. gemina, or A. mellea. In addition, the A. gallica nuclear DNA content was about $25 \%$ larger than $A$. nabsnona, and about $10 \%$ larger than $A$. calvescens, A. sinapina (except ST13), NABS X, and NABS XI. Motta et al (1986) reported a $32 \%$ difference between nuclear DNA content of $A$. mellea s. s. and $A$. bulbosa $(=A$. gallica) using microspectrophotometric analysis $(n=50)$. Thus, genome size represents a useful diagnosic characteristic to distinguish select species of Armillaria.

Flow cytometric quantification of DNA is also a useful tool for basic studies in fungal cell biology. Using flow cytometric analysis of nuclei isolated from spores and mycorrhizal roots of leek, Bianciotto et al (1995) demonstrated that colonization of a host by an arbuscular mycorrhizal fungus, G. versiforme, is linked to activation of its cell cycle. In this same manner, flow cytometry could also assist the study of ploidy 
levels through the life cycle of Armillaria species. Vegetative mycelia (e.g., mycelial fan or rhizomorphs) and mated cultures of Armillaria species typically exist in the diploid state (Franklin et al 1983, Korhonen 1980, Ullrich and Anderson 1978), in contrast to the dikaryotic state of most basidiomycetes. In our preliminary flow cytometry work with 45 vegetative (rhizomorph or mycelial fan) isolates, we also found that nuclear DNA contents were consistent with a primarily diploid condition, as exemplified by $A$. ostoyae (ca $0.12 \mathrm{pg}$ per nucleus), A. sinapina (ca $0.15 \mathrm{pg}$ per nucleus), NABS X (ca $0.16 \mathrm{pg}$ per nucleus), and $A$. gallica (ca 0.18 pg per nucleus). With these 45 vegetative isolates, only one isolate of $A$. ostoyae showed a nuclear DNA content indicative of a triploid condition (ca 0.175 pg per nucleus) (Kim et al unpubl). Our present results show the nine Armillaria species possess nuclei with a homogeneous unimodal distribution, pointing to a single ploidy level in all isolates (FIG. 1). Therefore, diploid nuclear DNA contents of nine North American Armillaria species are from $0.113 \mathrm{pg}$ (A. ostoyae) to $0.168 \mathrm{pg}$ (A. gallica) per $2 \mathrm{C}$, depending on species (TABLE III).

The nuclear DNA content $(0.237$ pg per nucleus) of A. sinapina isolate ST13, which originated from a multisporous isolation, is indicative of a triploid nuclear condition. Nuclear DNA contents of the other isolates of A. sinapina (ST12, M50) were $0.149 \mathrm{pg}$ and 0.151 pg per 2C, respectively (TABLE II). The fluorescence intensity of ST13 showed a homogeneous unimodal distribution (FIG. 1E), and microscopic observation of DAPI-stained nuclei revealed a monokaryotic condition. In previous studies on genetic exchange between diploid and haploid mycelia of A. gallica, Carvalho et al (1995) presented evidence that triploidy occasionally occurs. The biological significance and origin of triploidy, exemplified by $A$. sinapina isolate ST13, is unknown at this point. The natural prevalence of triploidy or other polyploidy is also unknown for other Armillaria species. Ploidy level could potentially influence mating, compatibility, adaptation, reproduction, pathogenicity, or other interactions with the biotic and abiotic environments. Continued studies with flow cytometry can help determine the role of polyploidy in the ecology of Armillaria species.

Diploidization of mated Armillaria cultures among interspecific species can also be assessed using flow cytometry. Verification of diploidization (or nuclear combination) can help verify mating among intraspecific and interspecific crosses. Studies on compatibility among Armillaria species frequently indicate a low-frequency compatibility among isolates ascribed to separate species. Examples of low-frequency compatibility include isolates of $A$. sinapina paired with isolates of $A$. cepistipes, NABS X, or NABS XI (Anderson et al 1980, Banik and Burdsall 1998, Bérubé et al 1996). Isolates of $A$. cepistipes have shown a lowfrequency compatibility with isolates of NABS X (Anderson et al 1980, McDonald et al 1998), and NABS $\mathrm{X}$ isolates have shown low-frequency compatibility with NABS XI isolates (Banik and Burdsall 1998). Although low-frequency compatibility does not necessarily indicate conspecificity, it does represent a possible mechanism for gene flow among species. Thus, our results show that flow cytometric techniques can help assess questions of nuclear status during the cell cycle of Armillaria species and address gene flow issues among Armillaria species.

For most isolates, RFLP patterns from Alu I cut IGS-1 were similar to those reported previously. However, isolates used in this study also produced IGS-1 RFLPs that were previously unreported. The IGS-1 RFLPs of A. gemina (ST8), A. calvescens (ST3, ST17, and ST18), A. mellea (ST5), and A. gallica (M70 and ST22) were not observed in previous reports of these species.

Amplified IGS-1 of A. ostoyae and A. gemina (except ST8) showed identical RFLP banding patterns following an Alu I cut (FIG. 2). Previous studies have shown that these species possess similar morphological (Bérubé and Dessureault 1988) and molecular characteristics (Anderson and Stasovski 1992, Piercey-Normore et al 1998). In addition, our study shows that nuclear DNA contents of these two species are not significantly different (TABLE III). Previous studies imply that speciation has occurred quite recently in the A. ostoyae $A$. gemina group; however, it is not completely clear which species is ancestral (Anderson and Stasovski 1992, Piercey-Normore et al 1998). Armillaria gemina ST8 had an additional fragment of $168 \mathrm{bp}$, possibly resulting from a $28 \mathrm{bp}$ deletion in the 196 bp fragment (FIG. 2 lane 4). White et al (1998) reported a similar deletion pattern from $A$. ostoyae. With isolates in our study, $A$. ostoyae and $A$. gemina were distinguishable with an Nde I cut IGS-1.

The new RFLP pattern for Alu I cut IGS-1 of $A$. calvescens (ST3, ST17, and ST18) is identical with one isolate of $A$. sinapina (ST12) (TABLE II, FIG. 2). Other studies have also shown this banding pattern is shared by $A$. gallica and $A$. sinapina (Banik et al 1996, Harrington and Wingfield 1995, White et al 1998). However, previously reported banding patterns of the $A$. gallica isolates were distinct from the pattern of $A$. calvescens or A. sinapina isolates in our study (TABle II, Fig. 2 lanes 16-18). One banding pattern of $A$. gallica (585, 234 bp, FIG. 2 lane 18) was observed previously with $A$. gallica $(582,240 \mathrm{bp})$ and A. calvescens $(582,240 \mathrm{bp})$ (Harrington and Wingfield 1995). Harrington and Wingfield (1995) could 
not differentiate between $A$. gallica and A. calvescens using several restriction enzyme digestions. In our study, restriction digestions with $B s m$ I, $D d e$ I, EcoR I, Hae III, Hinc II, and Nde I failed to differentiate between isolates of $A$. calvescens and A. sinapina (data not shown). We also attempted to differentiate these two species using Alu I, EcoR I, Hinc II, and Nde I restriction cuts of PCR-amplified ITS (internal transcribed spacer) region, but found identical banding patterns with both species (data not shown). Somatic pairing tests can distinguish among $A$. calvescens, $A$. sinapina, and A. gallica (McDonald unpubl). However, definitive PCR-RFLP species identification among these species may require additional restriction enzymes or assessments of variation in other DNA regions. Sequence analysis of IGS, ITS, or other diagnostic regions may provide information useful for distinguishing these species and addressing questions concerning evolution of this group.

An overriding goal of this study was to better characterize a set of diploid tester strains for use as references in future research. The determination of genome size and RFLP characterization of IGS-1 provide a critical basis for biological characterization of Armillaria spp. Further studies will characterize additional features of these and other isolates of Armillaria species. Directly or indirectly, such efforts should contribute to a better understanding of biological, ecological, and taxonomic relationships among Armillaria species.

\section{ACKNOWLEDGMENTS}

The paper was supported in part by the Biotechnology Graduate Research Associateship program of the Center for Biotechnology (UNL), the Storkan-Hanes Foundation, the Department of Plant Pathology at the University of Nebraska-Lincoln, and Nebraska Statewide Arboretum Graduate Research Fellowship. The authors thank Drs. Alan Harvey, Mike Larsen, Gary Yuen, and Phil Wargo for their comments on earlier versions of this manuscript. We also thank Drs. Harold Burdsall and Duncan Morrison for Armillaria isolates, and Mr. James Donley and Mr. Richard Carman for technical assistance. Use of trade names in this paper does not constitute endorsement by the USDA Forest Service.

\section{LITERATURE CITED}

Allman R. 1992. Characterization of fungal spores using flow cytometry. Mycol Res 96:1016-1018.

Anderson JB, Bailey SS, Pukkila PJ. 1989. Variation in ribosomal DNA among biological species of Armillaria, a genus of root-infecting fungi. Evolution 43:16521662.

- Kohn LM. 1995. Clonality in soilborne, plant-pathogenic fungi. Annu Rev Phytopathol 33:369-391.
- Korhonen K, Ullrich RC. 1980. Relationships between European and North American biological species of Armillaria mellea. Exp Mycol 4:87-95.

—, Petsche DM, Smith ML. 1987. Restriction fragment polymorphisms in biological species of Armillaria mellea. Mycologia 79:69-76.

—, Stasovski E. 1992. Molecular phylogeny of Northern Hemisphere species of Armillaria. Mycologia 84:506516.

- Ullrich RC. 1979. Biological species of Armillaria mellea in North America. Mycologia 71:402-414.

Arumuganathan K, Earle ED. 1991. Nuclear DNA content of some important plant species. Pl Mol Biol Reporter 9:208-218.

Banik MT, Burdsall HH Jr. 1998. Assessment of compatibility in vitro among Armillaria cepistipes, A. sinapina, and North American biological species X and XI, using culture morphology and molecular biology. Mycologia 90: 798-805.

— Volk TJ, Burdsall HH Jr. 1996. Armillaria species of the Olympic Peninsula of Washington state, including confirmation of North American biological species XI. Mycologia 88:492-496.

Bianciotto V, Barbiero G, Bonfante P. 1995. Analysis of the cell cycle in an arbuscular mycorrhizal fungus by flow cytometry and bromodeoxyuridine labelling. Protoplasma 188:161-169.

— B Bonfante P. 1992. Quantification of the nuclear DNA content of two arbuscular mycorrhizal fungi. Mycol Res 96:1071-1076.

Baumgartner K, Raabe RD, Rizzo DM. 1997. Identification and distribution of Armillaria species in California. Phytopathology 87:S7. (Abstract)

Bérubé JA, Dessureault M. 1988. Morphological characterization of Armillaria ostoyae and Armillaria sinapina sp. nov. Can J Bot 66:2027-2034.

$\longrightarrow, \longrightarrow$, Berthelay S, Guillaumin JJ. 1996. Interfertility among Armillaria cepistipes and A. sinapina. Phytoprotection 77:67-74.

Carvalho DB, Smith ML, Anderson, JB. 1995. Genetic exchange between diploid and haploid mycelia of Armillaria gallica. Mycol Res 99:641-647.

Darmono TW, Burdsall HH Jr. 1993. The nuclear status of the in vitro vegetative mycelium of Armillaria mellea. In: Johansson M, Stenlid J, eds. Proceedings of the Eighth International Conference on Root and Butt Rots, IUFRO working party S2.06.01. 9-16 August 1993, Wik, Sweden and Haikko, Finland. Uppsala: Swedish University of Agricultural Sciences. p 512-519.

Duchesne LC, Anderson JB. 1990. Location and direction of transcription of the $5 \mathrm{~S}$ rRNA gene in Armillaria. Mycol Res 94:266-269.

Duran G, Gray M. 1989. Nuclear DNA, an adjunct to morphology in fungal taxonomy. Mycotaxon 36:205-219.

Eilam T, Bushnell WR, Anikster Y. 1994. Relative nuclear DNA content of rust fungi estimated by flow cytometry of propidium iodide-stained pycniospores. Phytopathology 84:728-735.

Franklin AL, Filion WG, Anderson JB. 1983. Determination of nuclear DNA content in fungi using mithramycin; 
vegetative diploidy in Armillaria mellea confirmed. Can J Microbiol 29:1179-1183.

Frontz TM, Davis DD, Bunyard BA, Royse DJ. 1998. Identification of Armillaria species isolated from bigtooth aspen based on rDNA RFLP analysis. Can J For Res 28: 141-149.

Galbraith DW, Harkins KR, Maddox JM, Ayres NM, Sharma DP, Firoozabady E. 1983. Rapid flow cytometric analysis of the cell cycle in intact plant tissues. Science 220: 1049-1051.

Harrington TC, Wingfield BD. 1995. A PCR-based identification method for species of Armillaria. Mycologia 87: 280-288.

Hultquist SJ, Vogel KP, Lee DJ, Arumuganathan K, Kaeppler S. 1996. Chloroplast DNA and nuclear DNA content variations among cultivars of switchgrass, Panicum virgatum L. Crop Sci 36:1049-1052.

Jahnke K-D, Bahnweg G, Worrall JJ. 1987. Species delimitation in the Armillaria mellea complex by analysis of nuclear and mitochondrial DNAs. Trans Br Mycol Soc 88:572-575.

Korhonen K. 1978. Infertility and clonal size in the Armillaria complex. Karstenia 18:31-42.

- 1980. The origin of clamped and clampless basidia in Armillaria ostoyae. Karstenia 20:23-27.

McDonald GI, Larsen MJ, Klopfenstein NB, Kim M-S. 1998. Mating A. cepistipes and North American Biological Species (NABS) X. Phytopathology 88:S60. (Abstract)

Miller OK, Johnson JJ, Burdsall HH Jr, Flynn T. 1994. Species delimitation in North American species of Armillaria as measured by DNA reassociation. Mycol Res 98 : 1005-1011.

Motta JJ. 1985. Evidence for significant differences in nuclear DNA content between two geographically isolated clones of Armillaria mellea. Am J Bot 72:1307-1310.

—, Peabody DC, Peabody RB. 1986. Quantitative difference in nuclear DNA content between Armillaria mellea and Armillaria bulbosa. Mycologia 78:963-965.

Ota Y, Fukuda K, Suzuki K. 1998. The nonheterothallic life cycle of Japanese Armillaria mellea. Mycologia 90:396405.

Peabody DC, Peabody RB. 1985. Widespread haploidy in monokaryotic cells of mature basidiocarps of Armillar- ia bulbosa, a member of the Armillaria mellea complex. Exp Mycol 9:212-220.

- _ - 1986. Nuclear volumes and DNA content of three stages in life cycle of Armillaria bulbosa. Mycologia 78:967-968.

Piercey-Normore MD, Egger KN, Bérubé JA. 1998. Molecular phylogeny and evolutionary divergence of North American Biological Species of Armillaria. Mol Phylogenet Evol 10:49-66.

[SAS] SAS Institute. 1996. SAS/STAT User's Guide. 6.11 ed. Cary, North Carolina: SAS Institute, Inc.

Schulze S, Bahnweg G, Moller EM, Sandermann H Jr. 1997. Identification of the genus Armillaria by specific amplification of an rDNA-ITS fragment and evaluation of genetic variation within $A$. ostoyae by rDNA-RFLP and RAPD analysis. Eur J For Path 27:225-239.

$\longrightarrow$ - - Tesche M, Sandermann H Jr. 1995. Identification of European Armillaria species by restrictionfragment-length polymorphisms of ribosomal DNA. Eur J For Path 25:214-223.

Smith ML, Anderson JB. 1989. Restriction fragment length polymorphisms in mitochondrial DNAs of Armillaria: identification of North American Biological species. Mycol Res 93:247-256.

—, Duchesne LC, Bruhn JN, Anderson JB. 1990. Mitochondrial genetics in a natural population of the plant pathogen Armillaria. Genetics 126:575-582.

Sung J-M, Yang K-J, Kim S-H, Harrington T. 1997. Taxonomic study of Korean Armillaria species based on biological characteristics and DNA analyses. Kor J Mycol 25: 46-67.

Ullrich RC, Anderson JB. 1978. Sex and diploidy in Armillaria mellea. Exp Mycol 2:119-129.

Veldman GM, Klootwijk J, de Regt VCHF, Rudi RJ. 1981. The primary and secondary structure of yeast $26 \mathrm{~S}$ rRNA. Nucl Acids Res 9:6935-6952.

Volk TJ, Burdsall HH Jr, Banik MT. 1996. Armillaria nabsnona, a new species from western North America. Mycologia 88:484-491.

White EE, Dubetz CP, Cruickshank MG, Morrison DJ. 1998. DNA diagnostic for Armillaria species in British Columbia: within and between species variation in the IGS-1 and IGS-2 regions. Mycologia 90:125-131. 